\title{
Unveiling a new taxonomy in education field
}

\author{
Muhamad Afzamiman Aripin', R. Hamzah², P. Setya ${ }^{3}$, M. H. M. Hisham ${ }^{4}$, M. I. Mohd Ishar \\ ${ }^{1,4,5}$ Department of Technical and Engineering Education, Universiti Teknologi Malaysia, Malaysia \\ ${ }^{2}$ Centre of Modern Languages and Human Sciences, Universiti Malaysia Pahang, Malaysia \\ ${ }^{3}$ Tourism Academy Mandala Bhakti, Indonesia
}

\section{Article Info}

Article history:

Received Dec 30, 2019

Revised Apr 18, 2020

Accepted Jul 20, 2020

\section{Keywords:}

Cognitive classification

Education

Holistic

Taxonomy

\begin{abstract}
Taxonomy is a set of hierarchical models that is applied to classify educational learning goals or objectives into a certain level of complexity. Many models have been developed and implemented to suit the educational settings of schools or educational institutions around the world. Realising the importance of educational taxonomy, the purpose of this paper is to explore the function and role of the taxonomy framework used in education, especially through the lens of Bloom, Anderson and SOLO's (Structure of the Observed Learning Outcome) framework. In addition, this concept paper also aims to formulate a more holistic alternative taxonomy based on the concept of Syed Muhammad Naquib Al-Attas. Research on Bloom, Anderson and SOLO's taxonomies is not intended to deny the role and contribution of existing taxonomies, but to provide an alternative and space in creating a balanced system of cognitive classification of students through teaching and learning as well as in the evaluation system.
\end{abstract}

This is an open access article under the CC BY-SA license.

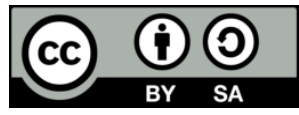

Corresponding Author:

Muhamad Afzamiman Aripin,

Department of Technical and Engineering Education, School of Education,

Faculty of Social Sciences and Humanities,

Universiti Teknologi Malaysia,

81310 Skudai, Johor, Malaysia.

Email: afzamiman@utm.my

\section{INTRODUCTION}

Taxonomy is a process or system in managing several groups of things that indicate the natural affinity of one another. Taxonomy terms are widely used in describing organic matters such as plants and animals. However, this term can also be found in the field of education for certain purposes. According to Hamdan [1], taxonomy in education is used to demonstrate a framework in classifying expectations on student achievement. For example, it can be used to draw up exam questions, measure the level of thinking and assess the extent to which the objectives of a lesson are met [2].

A taxonomy framework in the field of education measures a lot of cognitive-related things. In current studies, taxonomy in education has been used to measre characteristics of high order thinking skills, analysing cognitive abilities, and exam assessment [3-5]. Eng [6] and Nayef [7] describe various taxonomy forms for such purposes such as Anderson's taxonomy, Wilson's taxonomies, the SOLO taxonomy, and Bloom's taxonomy. Most of these taxonomy frameworks have similarities and differences. However, most are derived from Bloom's taxonomy that existed as early as 1956, which was later developed by education specialists in the following years [8].

Educational taxonomy has undergone many revisions to suit the current education system. Throughout this paper, the researcher has identified the surface learning process covered by Bloom, Anderson and Wilson's taxonomies. Meanwhile, the SOLO taxonomy elaborated the learning by extending 
the process to depth-learning. The depth-learning is a higher level of educational aim whereby effective elements such as love, integrity, empathy and discipline could be shaped and instilled [9]. The combined elements of some existing taxonomies turned out to be identical with the philosophy of human creation by Syed Muhammad Naquib al-attas as discussed by many scholars [10,11]. Therefore, this review paper is to build a new dimension of taxonomy based on his perspective as an alternative of a holistic taxonomy in the field of education.

\section{INTRODUCTION TO BLOOM'S WORK}

In 1956, Benjamin Bloom and a group of researchers developed an objective taxonomy of teaching that categorizes simple things into complexity and from facts to conceptual things [12]. There are six levels of division in his taxonomy i.e. knowledge, understanding, application, analysis, and systematic assessment $[2,6]$. The lowest order stages for high levels of cognitive thinking in teaching and learning are usually illustrated in the pyramid model in Figure 1.

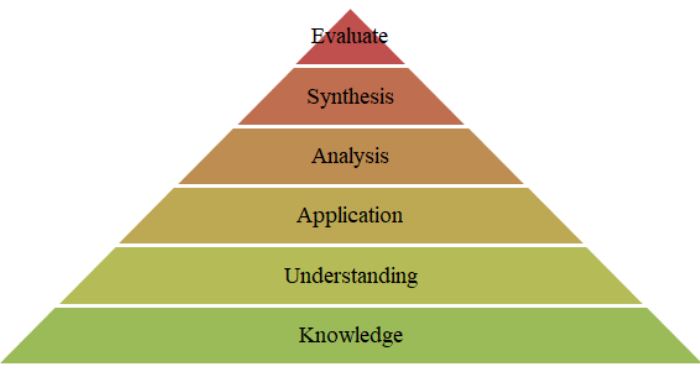

Figure 1. Bloom's taxonomy

Knowledge is the lowest stage of learning in this taxonomy before moving on to higher stages [7, 12]. Slavin [12] summarizes the descriptions of these six stages in an easy explanation. The level of understanding allows students to translate and use the information they receive. Nayef [7] stated that level of understanding makes a student able to anticipate the effects or consequences of an action. Application level also demonstrates the ability to use knowledge in a practical manner; for example, the ability of students to use knowledge to solve everyday problems. According to Slavin [12], a higher level is an analysis stage where students are able to link learning gained such as creating relevance and comparison, while the synthesis stage is a cognitive stage that demonstrates the ability of students to create something new and solve problems. The highest level of Bloom's taxonomy is the assessment where a student is able to decide against a criterion or standard on a matter.

This taxonomy has been used as reference in teaching and instructional planning for almost 50 years before it was revised by Anderson and Krathwohl in 2001 [13]. The weaknesses of Bloom's taxonomy were noted by Bloom himself. He realized that there was a fundamental difference between his "knowledge" category which are factual knowledge, conceptual knowledge and procedural knowledge, and the other five levels of his model which dealt with intellectual abilities and skills [13]. Bloom was also aware of the overlooking on the metacognitive knowledge category in his classification of knowledge.

\section{ANDERSON \& KRATHWOHL, WILSON TAXONOMIES}

A comparison was also made by Knorr [5] on the reforms of the Bloom's taxonomy framework over the framework suggested by Anderson and Krathwohl in Anderson's taxonomy, where the process of assessment and synthesis has changed position where he believes the highest level should be the ability to produce something new. The description of this difference can be seen in Figure 2. In Wilson's taxonomy, the change is to convert these six stages into four stages. According to Knorr [5], this does not mean that the synthesis and evaluation phases do not exist; rather, they are actually combined together in the analysis phase. Figure 3 shows the Wilson taxonomic model summarized from the original model of Bloom's taxonomy. 


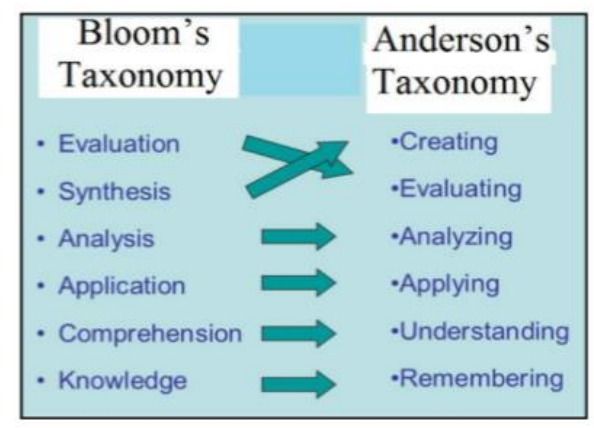

Figure 2. Anderson's taxonomy

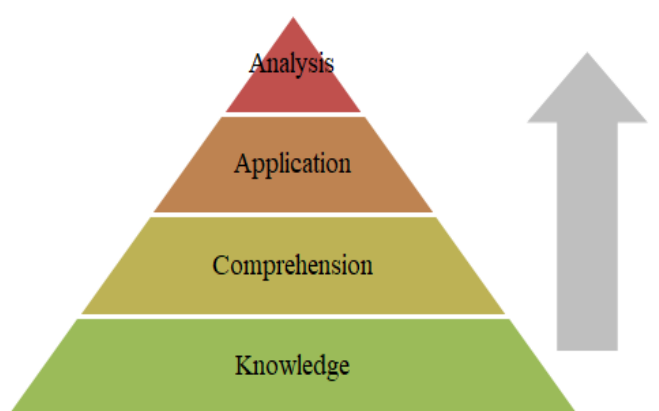

Figure 3. Wilson's taxonomy

In a discussion conducted by Ringo, Samsudin and Ramalis [4], Bloom's taxonomy has several advantages over Anderson and Wilson's taxonomies. However, the comparisons made are weak. For example, Bloom's taxonomy is more thorough in determining learning objectives. The fact is that Bloom's and Anderson's taxonomies have no difference in the number of items in achieving learning objectives. Bloom's taxonomy is widely used in many studies and has proven its effectiveness in evaluating teaching. The early existence of Bloom's taxonomy became the basis of other taxonomic studies to make Bloom's taxonomy known everywhere. This does not prove that it is better than other taxonomies. Other comparisons simply show Bloom's personal views on his taxonomic advantage through the writing of [2] and some other researchers who make this taxonomy as a reference as it can be understood by many in determining the objectives and processes in teaching.

The real advantage in Bloom's taxonomy is in terms of the number of items and processes that are more detailed and recognizable than other taxonomies [14]. However, in the SOLO taxonomy, little differences can be seen in some cases. The SOLO taxonomy is divided into two main divisions, namely surface learning and deep learning [15, 16]. According to [6], surface-level learning consists of facts, information and scope components and coverage. For deep learning, students are expected to be able to give meaning, to think deeply, to realize the purpose of life, and to reflect. Tsui [17] further explains that the two major divisions of the SOLO taxonomy are broken into five components, namely pre-structural, uni-structural, multi-structural, relational and extended abstract.

The SOLO taxonomy is not as well known as Bloom, Anderson and Wilson's taxonomies, but has a far-reaching view of the existence of a deep-seated component of learning. The advantages of deep-learning are not simply to lead to the ability to perform analysis, synthesis and evaluation, and even lead to the real meaning and purpose of learning. From the SOLO taxonomy, researchers are keen to see the probability of the existence of educationalism in Islam through the notion of a prominent scholar, Syed Muhammad Naquib al-Attas, in solving the element of surface level learning and deep level learning.

\section{UNVEILING A NEW TAXONOMY IN SYED MUHAMMAD NAQUIB AL-ATTAS'S SCHOOLS OF THOUGHT}

As discussed previously, taxonomy in education is widely used in measuring things related to cognitive or student thinking. Before discussing cognitive matters that are a gift to human beings compared to other beings, it is more important to understand the concept of man himself. According to al-Attas [18], man has a dual nature. He is both body and soul, and he is at once a physical being and a spirit. Therefore, when we want to define the concept of man, we have to relate to this nature. Hence, there are two perspectives to discuss the concept of the human being, which is about his potential and his role. From the human potential perspective, the key words that have been used from Al-Quran is 'al-Insan'. The word 'alInsan' comes from basic word 'nasiya' which means 'forgetfulness'. This is one of human beings' attributes. We have a tendency to become forgetful because we lose awareness. Meanwhile, the word 'al-nas' is used as a collective word for human beings, which means seeing and being knowledgeable. This means a human being can learn from his observation in order to acquire knowledge, distinguish between right and wrong, and make decisions [18-22].

Therefore, the word al-Insan defines the ideal characteristic of human beings. A man with an al-Insan characteristic can use his external senses to get in touch with the physical world, think by using his intellectual potential, and is finally aware of the real purpose of his existence which relates to his spiritual potential. In other words, al-Insan refers to a man who has developed holistically from external senses and 
leads to intellectual and spiritual potential. Al-Insan is defined as a man who has a very close relationship with God. As a servant to God, the al-Insan is aware that God possesses the highest and amplest knowledge, and as a human being, he has very limited knowledge compared to his Creator. All of these capabilities of al-Insan can be educated through teaching and learning processes [18].

Al-Attas [18] states that the body, the heart and the mind bind the man to the Creator in the context of the purpose of the incident, attitudes and actions in life. With these elements, man is required to use his external senses (eyes, ears, touch etc) to observe and think, and the final impact of this process is to their heart by acknowledging the existence of God, and to obey and to worship Him [18]. The definition of the human being from this perspective has a very close relationship with the definition of man from his potential. His potential needs to be developed through education in order to prepare and enable him to play his role [20, 22]. In addition, with the mandate given, man must act in governing, managing, controlling and preserving nature in accordance with the will of Allah SWT. Without knowing this, man will remain in his nature of his forgetfulness which is the source of disobedience, tyranny, and ignorance.

According to Syed [23] in describing Ibn Khaldun's views on the 'human', human beings are intelligent and possess physical and spiritual potential. With the intelligence, humans always try to think and act rationally. With physical potential, humans develop their achievement by making decisions and act on his surrounding such as in politics and economics. With spiritual potential, humans build understanding and connect himself to the Creator. Adding to that point, human beings with intellectual and physical potential alone cannot develop a civilization. Without the spiritual aspect, social, political, economic and other physical developments will collapse. This is reflected in many previous and current civilisations such as pollution, congestion, moral problems, high cost of living, corruption and more.

We also found an alternative explanation by [19]. He defines human beings or humans as having two attributes that are the outer nature and inner nature. According to him, the outer nature of a human being is complemented by a variety of senses that allow an individual to continue to survive on earth. With the ability to smell, touch, feel, see and hear, a human's physical potential can be developed to keep on surviving for living. However, this physical potential of humans is also present in most other creatures including animals. So, what makes humans ahead of other creatures is the advantages bestowed on their inner nature compared to animals.

According to Shami, Mohd, and Hamzah [19], as well as sensory-equipped physical properties, there are also sensors that equip the inner attributes of a human being called the internal sense. Syed Naquib al-Attas indicated that the human soul is immortal and equipped with faculties which are variously called the spirit (ar-ruh), the self (an-nafs), the heart (al-qalb) and the intellect (al-'aql). Each of these terms has two meanings: one that refers to the physical and another to the spiritual aspect. This explanation was supported by Imam Al-Ghazali, a Muslim philosopher. He also indicated that the non-physical man consists of the elements soul (ruh), heart (qalb), the self (nafs) and intellect ('aql). These elements share the same meaning, known as the "spiritual emotion toward God". This meaning is a unifying meaning in his definition about the real self or the inner nature of every human being [3].

Therefore, the soul (ruh) is considered a universal spirit within us, and remains unchanged and is a divine inspiration in a pure stare until we die [24]. The soul gives life to hearts (qalb). The qalb is the core of a human being that gives answer to who you are and is able to make a choice between right and wrong $[18,25]$. Originally, the qalb (heart) of man is pure, but when a man does evil deeds, it marks a stain on his heart. If a person does not repent, the stains spread more and more until the qalb cannot receive correct information from the soul. Therefore, the man's ability to differentiate between right and wrong will reduce and see things in the inverse whereby what is right is wrong and what is wrong is right. Meanwhile, the 'aql is the tool to develop intellectual capability and enables man to acquire knowledge. However, the true meaning of knowledge is to arrive at knowledge about God or the real concept of the Creator. Therefore, the seat of knowledge in man is a spiritual substance which is his heart and the 'aql remain as an important tool to acquire knowledge [26].

The self (nafs) concentrates on the commanding quality of the conscious self. There are three unseparated stages of the self which are al-Ammarah, al-Lawwamah and al-Mutma'inniah. The self, al-Ammarah, is the lowest stage in the self-development process and is known as the impulsive mind which a man shares with animals. This is a negative power that will imprison a man in his body (physical) or material needs and forget Allah. The main effect of al-nafs al-ammarah is to paralyze the cognitive processes [25, 27]. Therefore, the self (nafs) will always urge human beings to fulfil their physical or body or material needs. Hence, a man who leads his life based on the basic instincts of physical needs is just like an animal with needs for food, sleep, feel safe and others. According to [18], this is the lowest level of the human development stage. At this level, there is no uniqueness in the subjective side of humans and animals as both act on the same instinct of survival. This is not simply a theory because in many behavioral psychology studies, animals are used as an experimental medium before being applied to humans, including in education. 
For example, the works of a Russian scientist, Ivan Pavlov, with dogs show how the animals interact over their surroundings and learn through the experience they have. A similar study by Thorndike used cats in experiments and introduced the Law of Effect in learning. Skinner used mice and pigeons to study behaviors through effects on an action [12].

Meanwhile, the self of al-Lawammah is the conscientious or morally aware mind that struggles between good and evil. This is the power of armies engaged in a constant battle of alternate success. It relates to qalb or the middle stage of self-awareness. Man at this level falls into a confused state of mind. Sometimes, it is drawn towards its intellectual powers and encounters the intelligible whereby their eternal truths cause him to affirm his loyalty to God; sometimes, its animal powers drag it down to the lowest foothills of the bestial nature. The self is in an earnest struggle with its animal powers. By means of knowledge, moral excellence and good work, it is possible for man to attain the highest level which is the self al-Mutma'inah [18, 23]. The highest stage of the self (al-Mutma'innah), also known as the rational soul, is the mind perfectly in tune with God's will or the mind in peace. This is the purest stage of the self and can only be achieved when he inclines himself towards the right direction [28, 29]. The soul (ar-ruh) and the self (an-nafs) is not the same entity. The soul is fine and light. The function of the soul is to attract the self to a higher level which is close to Allah SWT. Figure 4 illustrates the stages of the conscious self (nafs).

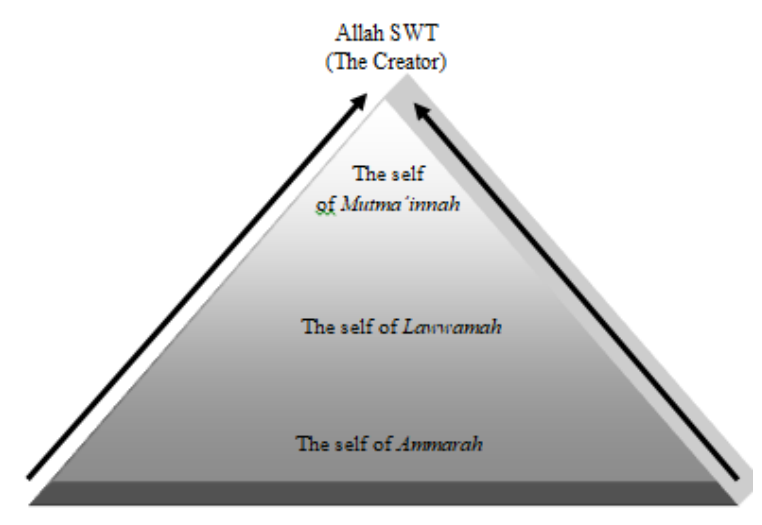

Figure 4. Wilson's taxonomy

In order to succeed, human beings have to strengthen their heart to put the self under the control of the soul energy [24]. At this stage, human beings will develop internal control to control the self and develop his rational thinking to be moderate in assessment of his physical needs. Based on the above discussion, the researcher found that some of the processes discussed above are cognitive creation methods in the education process. Frameworks from the description of Syed Muhammad Naquib al-Attas and some of the above sources allow another franchise to be framed and compared to the existing taxonomy. Table 1 shows the comparison of Bloom's taxonomy combined with the SOLO taxonomy and compared with the new taxonomy framework. From the discussion, a new framework of the taxonomy model as in Figure 5 has been proposed. This taxonomy provides a more holistic view in the implementation of teaching and learning processes and covers the process of surface and deep learning.

The diagram in this taxonomy presents every step of the knowledge development process in education. The most important innovation point is the development of the physical, intellectual and spiritual potential which has been united to the main purpose of education which is to develop belief and faith to the Creator and to enslave oneself to Him and play the role as vicegerent or khalifah on the earth [30]. Moreover, self awareness of pure submission to God will give the right direction to human life [31, 32]. Therefore, the terms of change, progress and development in a man's life should refer to a definite direction that is the final vision of life to be achieved in this worldly life [18,32]. This could be achieved by developing curriculum that provides experience and problems to solve in real life [33]. However, the learning process begins with information and becomes an obligation for instructors to make every student develop the highest level of learning to realise that it is an obligation to abide with universal values through their belief system. 
Table 1. Bloom's taxonomic comparison, SOLO and the taxonomic framework derived from Syed Muhammad Naquib al-Attas

\begin{tabular}{|c|c|c|c|}
\hline $\begin{array}{c}\text { Combined Bloom's Taxonomy } \\
\text { and SOLO Taxonomy }\end{array}$ & $\begin{array}{l}\text { Taxonon } \\
\text { Syed Ml }\end{array}$ & $\begin{array}{l}\text { ework driven from } \\
\text { ad Naquib al-Attas }\end{array}$ & Level of The Self (an-nafs) \\
\hline $\begin{array}{l}\text { The surface learning } \\
\text { component of Bloom's } \\
\text { Taxonomy; } \\
\text { a. Knowledge } \\
\text { b. Understanding } \\
\text { c. Application } \\
\text { d. Analysis } \\
\text { e. Synthesis } \\
\text { f. Assessment } \\
\text { Deep learning component of } \\
\text { SOLO Taxonomy; } \\
\text { a. Meaning } \\
\text { b. Deep thinking } \\
\text { c. The purpose of life } \\
\text { d. Reflection }\end{array}$ & $\begin{array}{l}\text { Physical potential } \\
\text { (External Senses) } \\
\text { - Touch } \\
\text { - Feel } \\
\text { - Observe } \\
\text { - Just like animal }\end{array}$ & $\begin{array}{l}\text { Thinking: } \\
\text { - Understand } \\
\text { - Analysis } \\
\text { - Synthesis } \\
\text { - Assessment } \\
\text { Qalb (Seat of Knowledge) } \\
\text { Deep thinking (Hidden } \\
\text { meaning of life): } \\
\text { - Who am I } \\
\text { - Purpose of life } \\
\text { - Reflect on } \\
\text { define/religious science } \\
\text { - Acknowledge the } \\
\text { Creator as the Lord of } \\
\text { mankind } \\
\text { - Feel closer to the Creator } \\
\text { - Strengthen belief and } \\
\text { faith to the Creator } \\
\text { - Rearrange his life as } \\
\text { slave and vicegerent to } \\
\text { the Creator } \\
\text { Ruh }\end{array}$ & $\begin{array}{l}\text { Al-amarah } \\
\text { - No thinking } \\
\text { - Ability tio fulfil body and } \\
\text { physical needs } \\
\text { Al-Lawarmmah } \\
\text { - Struggling between good and } \\
\text { evil } \\
\text { - Confused stage of mind } \\
\text { Al-Mutma'imah } \\
\text { - Rational soul }\end{array}$ \\
\hline
\end{tabular}

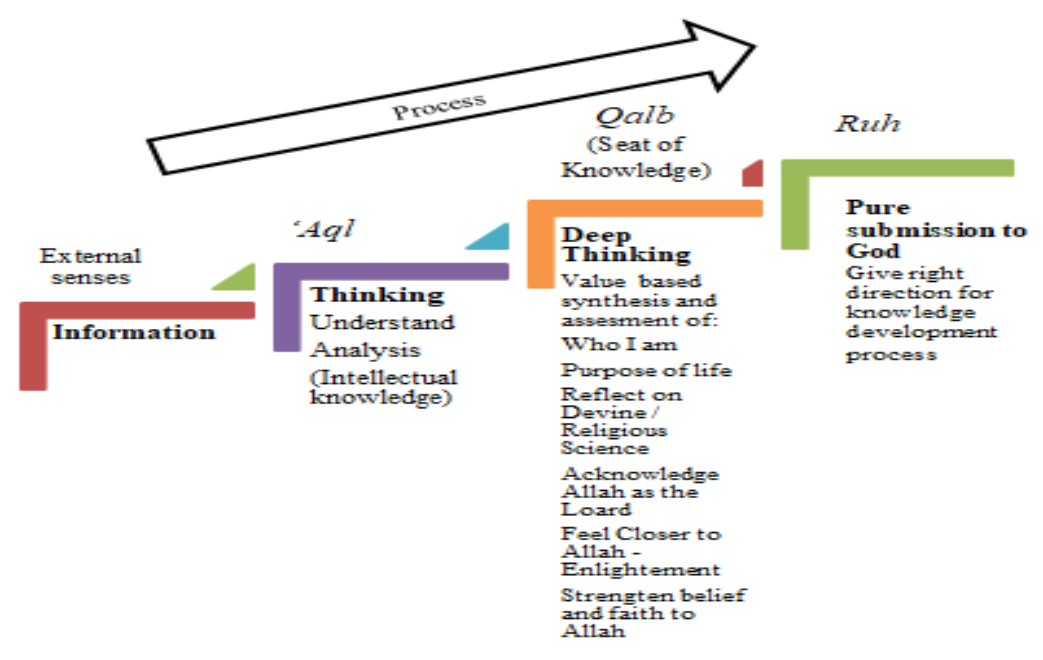

Figure 5. The holistic taxonomy

\section{CONCLUSION}

Based on the literature, Bloom, Anderson, and Wilson Taxonomy are lacking on the metacognition part of learner. Without denying their major contribution to the world of academic and education, these frameworks have strength in measuring something that is more objective and measureable. Due to the complexity of human being, a holistic model on human thinking taxonomy is required and need futher studies. By extending the understanding from SOLO Taxonomy, this article reviewed on holistic human being elements based on literature and tries to figure out the complexity of human creation according to a religion. The suggested framework of taxonomy in this literature is believed to be able to produce more 
excellent human capital in terms of emotional, spiritual, physical, and intellectual aspects as desired. However, this assumption must be explored based on more empirical evidence and thorough studies.

\section{REFERENCES}

[1] M. N. Hamdan Muhammad, Kurikulum Dari Langit. Selangor: Kemilau Publika, 2013.

[2] D. Krathwohl, "A Revision of Bloom's Taxonomy: An Overview," Theory Into Practice, vol. 4, no. 41, pp. 212-264, 2002.

[3] Ariyanto, R.O. and Mardiyana, Siswanto, "Characteristics of mathematics high order thinking skill problems levels," Journal of physics: Conference series, vol. 1470, 2020.

[4] Ringo, S. S., Samsudin, A., and Ramalis, T. R., "Utilizing rasch model to analyze A gender gap in students' cognitive ability on simple harmonic motion," Journal of physics: Conference series, vol. 1467, pp. 1-9, 2020.

[5] Knorr, E. M., "Worked examples, cognitive load, and exam assessments in a senior database course," Annual conference on innovation and technology in computer science education, ITiCSE, p. 612, 2020.

[6] J. A. J. Eng and B. Ramiah, Kepimpinan Instruksional; Satu Panduan Praktikal. Selangor: PTS Akademia, 2013.

[7] E. G. Nayef, N. R. N. Yaacob, and H. N. Ismail, "Taxonomies of Educational Objective Domain," International Journal of Academic Research in Business and Social Sciences, vol. 41, no. 9, pp. 165-175, 2013.

[8] A. W.N, F. B.W, D. A. and F. L., "Student profile in completing questions based on cognitive level of Bloom's Taxonomy by Anderson \& Krathwohl," in AIP Conference, vol. 2026, no. 1, 2018.

[9] W. Jeynes, "A meta-analysis on the relationship between character education and student achievement and behavioral outcomes," Education and Urban Society, vol. 1, no. 51, pp. 33-71, 2019.

[10] M. H., R. R.C., P. H. and M. S.J.N, "Malay language and the concept of true knowledge from the perspective of syed muhammad naquib al-attas," Kemanusiaan, vol. 1, no. 20, pp. 1-22, 2013.

[11] F. Ahmed, "An exploration of naquib al-attas' theory of islamic education as ta'dīb as an 'indigenous' educational philosophy," Educational Philosophy and Theory, vol. 50, no. 8, pp. 786-794, 2018.

[12] R. Slavin, Educational Psychology. Theory and Practice, 12 ed. United States of America: Pearson, 2018.

[13] L. O. Wilson, “Anderson and Krathwohl - Bloom's Taxonomy Revised," 2016. [Online]. Available: http://thesecondprinciple.com/teaching-essentials/beyond-bloom-cognitive-taxonomy-revised

[14] Radmehr F. and Drake M., "Exploring students' metacognitive knowledge: The case of integral calculus," Education Sciences, vol. 10, no. 3, pp. 1-20, 2020.

[15] H. J.A.C and G. Brown, "Cognitive processes in asTTle: The SOLO taxonomy," asTTle Report 43, 2004.

[16] J. Caniglia and M. Meadows, "An application of the solo taxonomy to classify strategies used by pre- service teachers to solve one question problems," Australian Journal of Teacher Education, vol. 9, no. 43, pp. 75-49, 2018.

[17] C. Chan, et al., "Applying the structure of the observed learning outcomes (SOLO) taxonomy on student's learning outcomes: An empirical study," Assessment \& Evaluation in Higher Education, vol. 41, no. 9, pp. 511-527, 2002.

[18] S. M. N. al-Attas, "The Nature of Man and the Psychological of the Huaman Soul. Abrief outline and a framework for an Islamic Psychology and Epistimology," International Institute of Islamic Thought and Civilisation IIUM, Selangor, 1990.

[19] A. M.A., S. Shami, H. Mohd and R. Hamzah, "Index of Instructional Sensitivity of Holistic Approach Training Module for Malaysian TVET Instructors in Prison," International JOurnal of Human and Technology (IJHaTI), vol. 2, no. 1, pp. 13-18, 2018.

[20] H. Rohana, Mengenali Manusia (Asas Pembangunan Manusia Berkualiti). Johor Baharu: Penerbit UTM Press, 2010.

[21] H. N. Abuddin, Falsafat Pendidikan Islam. Jakarta: Gaya Media Pratama, 2005.

[22] H. Rohana, Philosophy of Science and Ethic in Philosophy. Kuantan Pahang: Penerbit UMP, 2017.

[23] O. Syed, "The Muqaddimah of Ibnu Khaldun- Religion, Human Nature and Economics," Kolej Universiti Islam Antarabangsa Selangor, Selangor, 2008.

[24] M. al'Mahdi, Understand the development of the human personality and soul, Selangor: Khalif Institute, 2005.

[25] A. A. Zafar, "Qur'anic concepts of human psyche," The International Institute of Islamic Thought and Isntitute of Islamic Centre, Pakistan, 1992.

[26] W. D. Wan Mohd Nor, "Falsafah dan Amalan Pendidikan Islam; Syed M. Naquib Al-Attas: Satu huraian konsep asli islamisasi," Kuala Lumpur: University Malaya, 2005.

[27] A. Ibnu, Mencapai Ma'rifat; Satu Pendekatan. Kuala Lumpur: al-Hidayah, 2005.

[28] R. Fazlur, Major themes of the Quran. Petaling Jaya: Islamic Book Trust, 1999.

[29] I. Turmudi, et al., "Purpose of Education and Spiritual Potential; What is Your Definition?" Jurnal Teknologi, vol. 9 , no. 58, pp. 85-88, 2016.

[30] T. M. J. Tunku Sarah, "Pembinaan model penerapan nilai di dalam pengajaran di institusi pengajian tinggi (IPT)," Universiti Kebangsaan Malaysia, Selangor, 1997.

[31] Hamka, Falsafah Hidup. Selangor: Pustaka Hidup, 2009.

[32] Ummu Yasmin, Materi Tarbiyah. Panduan Kurikulum Bagi Da’i \& Murabbi, 5 ed. Indonesia: Media Insani Press, 2005.

[33] Permatasari BD, Gunarhadi, and Riyadi, "The influence of problem based learning towards social science learning outcomes viewed from learning interest," International Journal of Evaluation and Research in Education, vol. 8, no. 1, pp. 39-46, 2019. 